\title{
LOCALIZATION THEORY OF REGIONAL DEVELOPMENT AND AGGLOMERATION EFFECTS: A CASE STUDY OF THE ICT SECTOR IN THE CZECH REPUBLIC
}

\author{
Kamila TUREČKOV $\check{A}^{1}$
}

DOI: $10.21163 / \mathrm{GT} \_2018.131 .11$

\begin{abstract}
:
The localization theory of the regional development constitutes even these days the permanent groundwork for the possible explanations of the local distribution of the firms in relation to their economic prosperity and potential for the future development. In this paper, factors and contributions of the firm concentration will be theoretically defined using the theory of the core-periphery, taking into consideration their location either in the core of the region or in its periphery. The theoretical assumptions of the chosen subtheories of the group core-periphery, i.e. the theory of cumulative causation and the general theory of polarized development, will be confronted in the paper with the actual findings based on the questionnaire survey among the ICT firms in two regions of the Czech Republic, namely in The South Moravian Region and The Moravian-Silesian Region (NUTS3). The regional capital defined on the regional level of LAU1 formed the core of the region, while the periphery was formed by the remaining districts in the given region. The research confirmed that the ICT firms concentrated in the cores of the regions possess and are aware of the agglomeration effects (advantages) connected with the dominance of the positive (net) externalities combined with relatively undemanding mutual information sharing, knowledge, experience and innovation. The central agglomeration of concentrated ICT firms supports and creates conditions for the existence of the specialized (technological) infrastructure, the availability and sharing of the qualified workforce based on the advanced division of labour, and the participation in the sectoral arrangement (clusters), or more precisely in research and development centres. The discovered data unambiguously support the polarization of the chosen economic structures, specifically the economic sector of ICT, which is then reflected in the dynamic development of the innovation and the growth of investments, a highly specialized structure of workforce, the growth of living standards and the increase in the competitiveness of the given firms, and through the sector and the region leads to the growth of the competitiveness of the whole national economy.
\end{abstract}

Key-words: Core-periphery theory, Sectoral agglomeration, ICT sector, Regional Development, Czech Republic.

\section{INTRODUCTION}

Information and communication technologies (ICT) play a key role in the context of current societal and economic change. In the 1990s free and public information began to spread through the use of the internet and soon it was possible to produce, to access and to share own, private data. All these steps have led to the promotion of cooperation between different groups of actors, to the digitization of processes and the network integration of enterprises. Through information and communication technologies the process of incorporating foreign processes into their own business activities has been continually

\footnotetext{
${ }^{1}$ School of Business Administration in Karvina, Silesian University in Opava, Univerzitni Nam. 1934/3, 73340 Karvina, Czech Republic, tureckova@opf.slu.cz.
} 
stepped up in order to simplify, streamline and, in particular, to reduce and cost-effectively reduce the important, especially corporate, processes and activities (Friedman, 2006). The ICT sector continues to increase its share in the life of individuals, the functioning of businesses and public administration, and also plays an important role in product or service creation. Last but not least, it is an important factor affecting local, national and global economic performance (Basl, 2010). The ICT sector is characterized by multiplier effects in the economy, where activities in this sector directly or indirectly affect outputs in other sectors, contribute to significant savings and productivity gains, increased intellectual capital, the growth of social value generated by the synergy of knowledge, information and technology, which are being developed, developed and supported by this sector of the economy. All these positive effects associated with business activity in the ICT sector increase the competitiveness of the regions in which they operate and contribute to improving a quality of life and living standards (Turečková, 2017). The agglomerating process of territorial concentration of the ICT industry would be interested in ICT firms themselves and should be actively supported by their leadership and management as well as by the national economic authorities (see also Roche, 2016 or Hong \& Fu, 2011).

The selected theoretical approaches to regional development should define the theoretical benefits of the regional specialization in the ICT sector, respectively sectoral agglomeration of the ICT firms and define the factors that support this concentration process, i.e. to characterize the relevant causes of interregional differences forms the specific sectoral agglomerations. Generally defined localization factors of sectoral specialization related to the ICT sector include agglomeration savings related to the prevalence of positive (network) externalities, mutual sharing of information, knowledge, experience and innovation, the existence of specialized (technological) infrastructure, accessibility and sharing skilled labor based on advanced division of labor or the existence of sectoral clusters, respectively research and development centers (Pařil et al., 2015; Turečková, 2014 and Turečková, 2015).

Regarding the methodological perspective, the current research is based on economicgeographical methods which are part of Economic geography. On the background of localization theories were selected theories from the group of the "core-periphery" because of its most important contribution of localization theories that can be referred to as the development of agglomeration effects, which are part of regional development theories today (Šimanová \& Trešl, 2011 and Baldwin et al., 2005).

The objective of this paper is to determine differences in the perception of the sectoral concentration between the core (centre) of the region and its periphery. In particular, we will be interested in some agglomeration effects and their differences with respect the location of ICT firms in the region. This information was obtained through an email questionnaire survey done between ICT firms that have been conducted in the area of two regions on regional level NUTS3 in the Czech Republic. These regions are The South Moravian Region and The Moravian-Silesian Region at the turn of the years 2016 and 2017.

The article is organized as follows. Section "Theoretical framework of the study" describes the theoretical approach towards the sectoral concentration in the context of theory "core-periphery" with an emphasis on the main theoretical contributions to this problem. Most of the questions used in the questionnaire survey were based on finding out from the theoretical background. The section "Methodology and data" provide information about primary survey and research. The next section "Agglomeration effects of ICT firms in the core and in the periphery" presents concrete basic empirical results on differences 
between centre and periphery. The last part, the conclusion, provides us with concluding comments, and it highlights some of the major conclusions from the analysis provided.

\section{THEORETICAL FRAMEWORK OF THE STUDY}

The presented paper is from the theoretical point of view based on economicgeographical assumptions of the "core-periphery" theory, especially on the theory of cumulative causes and the general theory of polarized development. The question asked is if there are some differences between the effects of the concentration of ICT firms located in the centres (core) and on the periphery of the region.

The core-periphery theory, respectively "the general theory of polarized development (regional imbalances)" was most intensely developed in the Keynesian period, especially in the 50's and 70's of the 20th century. The concepts of core-periphery have introduced by John Friedmann who used this term (word) at the first time. It was a set of partial theories explaining the long-standing divergent processes between regions in the context of the development in the sectoral structure of the economy, whose main theorists include $G$. Myrdal (1957), J. Friedmann (1966), F. Perroux (1950), A. Hirschman (1967) and D. North (1955). The assumption of these theories is unequal regional development and emphasis on the importance of factors on the demand side, especially investments. Other factors that cause regional divergence in the context of sectoral development include external savings, agglomeration benefits (savings), selective migration of labour, and mobility of capital (especially human). The theory assumes long-standing inequality in regional development, which requires the need for government intervention, which as the only institution in the country is capable of stopping the deepening process of regional divergence.

One of the most important ideas is the theory of cumulative causes of the Swedish economist Gunnar Myrdal (Myrdal, 1957) which argues that the change does not trigger a reaction in the opposite direction, but other changes that enhance it, i.e. a change in one factor will also change the orientation of other factors, the initial difference, i.e. the difference between the regions (the core) will be further deepened (periphery). Market forces, the movement of capital, resources and labour do not lead to a balance but cause widening of regional differences. In the context of its theory, the initial development of a region for whatever reason will cause the region to develop faster than other regions, and the differences between it and the group of other regions will continue to grow. In the less developed regions, resources (capital and prospective labour force) that accumulate in more developed regions are being drained.

Friedmann (1966) within the framework of his "general theory of polarized development", understands the centre as an autonomous region with the ability to capture the main impulse of the given development and to create the required innovations, while the periphery as an area that does not capture these changes. Strengthening dominance and deepening asymmetry of the centre over the periphery explains through six effects: (1) the effect of dominance, (2) the effect of links, (3) the information effect, (4) the psychological effect, (5) the modernization effect and (6) the production effect. The core has a better ability to generate innovation and achieves a greater degree of autonomy with respect to the periphery - independence from other regions. Friedmann's theory is significant in view of the fact that it does not only cover a narrow range of economic variables (for example in comparison to Perroux's economic theory) but emphasizes the importance of institutional structures and social, political and cultural developments in the geographic space (behavioural factors for regional development). 
Perroux (1950) in his theory of growth poles, emphasizes the importance of crosssectoral links, the regional multiplier, and the existence of agglomeration savings that cause the growth of some driving industries at the expense of others. The driving industry in the region is one that is rapidly developing against the backdrop of large and innovative firms. These differences in economic structure are behind the rise and growth of interregional differences. In this case, unequal development is considered to be self-evident as growth cannot occur everywhere and on the same scale. Another concept introduced by Perroux is the growth pole, a certain point (place), respectively points (places) in time and space that lead to growth (Wokoun et al., 2008).

Hirschmann (1967) perceives interregional differences as a basic, natural and indispensable condition for growth where regions (cores) with agglomerating advantages are more abundant at the expense of peripheral areas that lag behind the "cores". Thus cyclical causality processes occur in the territory which in the context of dissertation work can be characterized as the long-term development of the sectoral core (cores) and the decline of sectoral activities on the periphery. Cores are characterized by advanced infrastructure and a higher level of knowledge and skills that are characteristic of a skilled workforce.

The core-periphery theory began to be criticized at the end of the 1960s, particularly by J. R. Lasuén (1969) who accused them of neglecting institutional issues and abandoning the concept of innovation. On the other hand, Lasuén supported and emphasized the importance of innovation (especially their creation and implementation) as a key element for the development of the economy. At the same time, he emphasized the growth potential of the tertiary and quaternary sector firms (Higgins, Higgins \& Savoie, 1995).

On the same background was elaborated the concept of sectoral industrial agglomeration at the beginning of the 21 st century where firms are concentrated on a certain, limited territory, operating mainly in the same sector, interconnected by a network of mutually meaningful and non-binding relationships and links that complement other participating private and public institutions that are with the firms or industries concerned, direct or indirect and exist in the same territory. The reason for the evolutionary formation and the existence of industrial agglomerations are the benefits of participation in this agglomeration, especially in the form of deepening specialization, externalities and economies of scale (Turečková, 2015 or Campos, 2012). For example, Kim et al. (2009) based on the DEA method demonstrated a positive effect of externalities on the efficiency of the biotech industry in the USA. Driffield and Munday (2001) in their UK research have confirmed that the regionally concentrated industry improves its technical efficiency and shifts it to the production possibilities. The most concentrated manufacturing enterprises showed the highest production efficiency. Mitra and Sato (2007) and Otsuka and Goto (2015) came to similar conclusions. Improving efficiency and enhancing competitiveness resulting from the concentration of firms was confirmed at the microeconomic level in the textile industry in India (Mitra, 1999), salmon production in Norway (Tveteras \& Battese, 2006) and in tourism industry in Czech Republic (Ruda, 2016).

\section{METHODOLOGY AND DATA}

As a first step of the presented research, detailed literature retrieval was performed to understand the problem, nature and specifics of the localization theory of regional development and agglomeration effects of the concentration of firms. From these theories and in context of the aim of the research was selected a group of theorems "core- 
periphery", especially the theory of cumulative causes and the general theory of polarized development which were extended by the concept of the sectoral agglomerations. There were defined question and structure of the questionnaire based on these theoretical approaches.

\section{The South Moravian Region (SMR)}

\section{The Moravian-Silesian Region (MSR)}
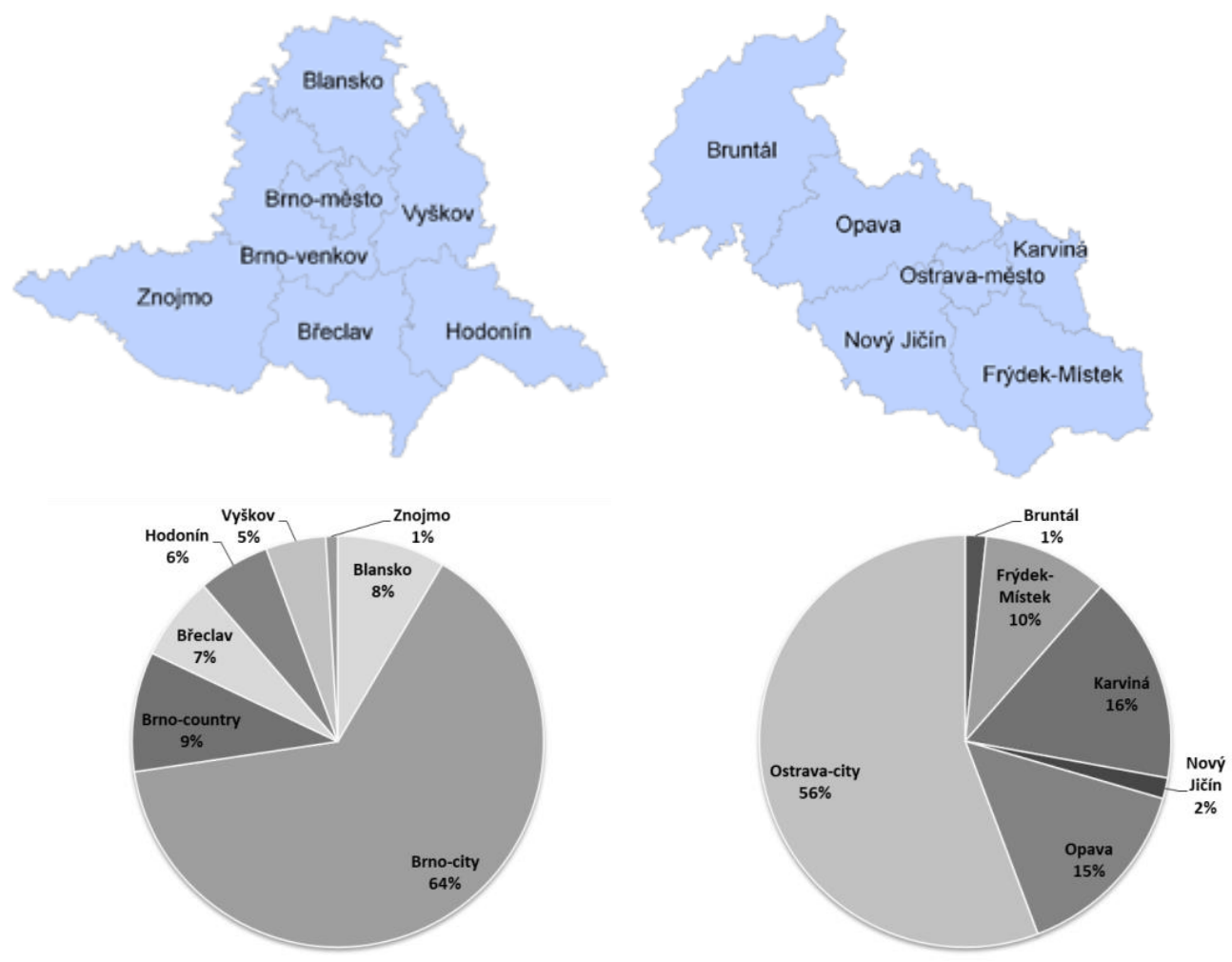

Fig.1 Localization of the ICT firms (nSMR=106, nMSR=61).

Sources: Regional Information Service and questionnaire survey, own processing, 2017.

Primary data to determine the effects of ICT firm's agglomeration was obtained via email questionnaire survey (email correspondence). Individual phases of conducted research were performed simultaneously in two Czech regions on level NUTS3, in The South Moravian Region (SMR) and in The Moravian-Silesian Region (MSR) in 2016 and 2017 (Fig. 1). These two regions were selected against the background of previous studies on regional disparities (Turečková \& Nevima, 2017 or Turečková, 2017). In order to ensure the electronic addresses of ICT companies, MERK company database by IMPER CZ, s.r.o. was used. The questionnaire survey was done among 1601 firms operating in the ICT sector (1021 firms in The South Moravian Region and 580 firms in The Moravian-Silesian Region. The ICT sector is defined by NACE Rev. 2, Section J. The return was 167 completed questionnaires, what mean $10.43 \%$ of the total number of respondents. The questionnaire has been created on the basis of previous studies and contained 9 questions 
concerning the aspects of the company's position in the context of the agglomeration (sectoral concentration) effects and the six questions to identification issues characterizing the firm's respondents. The evaluation of the data obtained took into account the division of firms into the centres (cores) of the regions (regional cities on regional level LAU1) and their periphery (the rest regions LAU1 of the region NUTS3).

If we distribute ICT firms to firms located in the centre (core) and the periphery we have 102 firms in the centre and 65 firms located in the periphery. This division is very important for the further analysis of the agglomeration effects and is necessary to get required results. This is the main content of the next chapter.

\section{RESULTS - AGGLOMERATION EFFECTS OF ICT FIRMS IN THE CORE AND IN THE PERIPHERY}

This part of the paper analyses the answers obtained from the questionnaire survey and puts it in context with the theoretical assumptions and conclusions resulting from selected regional development theories in the context of the division at the core and the periphery. As already mentioned earlier, the regional cities (centres) of two selected regions will be geographically defined by the territory of the LAU1 regions. It will be Brno-city and Ostrava-city. The remaining districts will form the periphery. In The South Moravian Region, the districts (periphery) defined by the regional level LAU1 as well are Blansko, Brno-country (Brno-venkov), Břeclav, Hodonín, Vyškov and Znojmo, in The MoravianSilesian Region there are Bruntál, Frýdek-Místek, Karviná, Nový Jičín and Opava.

\section{Distribution of ICT firms in the districts of The South Moravian Region and The Moravian-Silesian Region in 2008 and 2015}

\begin{tabular}{|l|c|c|c|c|c|c|c|}
\hline $\begin{array}{l}\text { Districts (LAU1) of } \\
\text { The South Moravian } \\
\text { Region/year }\end{array}$ & Blansko & $\begin{array}{c}\text { Brno - } \\
\text { city }\end{array}$ & $\begin{array}{c}\text { Brno - } \\
\text { country }\end{array}$ & Břeclav & Hodonín & Vyškov & Znojmo \\
\hline 2008 & $6.4 \%$ & $63.7 \%$ & $11.0 \%$ & $4.6 \%$ & $6.2 \%$ & $4.0 \%$ & $4.1 \%$ \\
\hline 2015 & $4.7 \%$ & $64.9 \%$ & $13.9 \%$ & $4.4 \%$ & $5.1 \%$ & $3.8 \%$ & $3.2 \%$ \\
\hline $\begin{array}{l}\text { Districts (LAU1) of } \\
\text { The Moravian- } \\
\text { Silesian Region/year }\end{array}$ & Bruntál & $\begin{array}{c}\text { Frýdek } \\
- \\
\text { Místek }\end{array}$ & Karviná & $\begin{array}{c}\text { Nový } \\
\text { Jičín }\end{array}$ & Opava & Ostrava - city \\
\hline 2008 & $5.7 \%$ & $16.1 \%$ & $18.3 \%$ & $9.3 \%$ & $10.3 \%$ & $40.3 \%$ \\
\hline 2015 & $5.4 \%$ & $16.2 \%$ & $16.0 \%$ & $10.5 \%$ & $13.0 \%$ & $38.9 \%$ \\
\hline
\end{tabular}

Source: Database of the Business Register, Czech Statistical Office, 2017.

Table 1 shows the relative distribution of ICT firms in the districts of the respective regions in 2008 and 2015 according to the Czech Statistical Office (Register of Economic Subjects). It can be seen from the Table 1 that in The South Moravian Region ICT firms are more concentrated in the Brno-city $(65 \%$; 2015), while in The Moravian-Silesian Region the distribution of ICT firms in the districts is not so polarized. Most firms are located in the Ostrava-city (less than 40\%, 2015). In The South Moravian Region, next 14\% of ICT firms are concentrated in the Brno-country, while in the other districts $21 \%$ of them are 
located. In The Moravian-Silesian Region, except the Bruntál district, the distribution in the remaining regions is rather even and ranges from $10.5 \%$ to $16.2 \%$. On the basis of the above, we can conclude that from the point of view of ICT firms, the centre of ICT sector in The South Moravian Region is Brno-city district and in The Moravian-Silesian Region it is Ostrava-City, but the position of this centre is not as strong as in the first case. There is also necessary to emphasize that the percentage of ICT firms in the districts of the analyzed regions corresponds to the distribution of firms in the answers received in the questionnaire survey.

Table 2 shows come different manifestations in the answers between centre and periphery. There is a considerable demand for higher education at technical staff in the centre (more than 22\%). Also, respondents from the core think that the wage in the centre is higher than usual which may be related to the difficulty of retaining employees what we can explain increased competition between firms spilling into the labour market. In the centre with the problem of retaining employees about 53\% of ICT companies while on the periphery it is only $37 \%$. ICT firms in the core also require higher education of their employees (in 47\%) than companies in other districts (in 25\%). What is surprising is the perceived independence of addressed firms from other ICT companies: in 65\% ICT firms feel to be independent as well as in the centre as well as on the periphery. For ICT firms in the centre are also characteristic that they know more other ICT firms (they know more than 5 similar firms around in 56\%) in their neighbourhood than the firms in peripheral parts of the region (only in $23 \%$ ). This can be explained by the higher concentration of ICT firms in smaller territorial areas and hence by increased market concentration when companies actually need to know their competitors. In Table 2, there is finally to be seen that the firms in the core (in 65\%) more aware of the positive effects of company concentration and be part of a sectoral agglomeration. Companies in the periphery in 54\% think it is good to be part of such an agglomeration. In both cases, ICT firms perceive the positive effects of company concentration.

Table 2.

Selected differences in the results of the questionnaire survey among cores and periphery in The South Moravian region and The Moravian-Silesian region (Czech Republic).

\begin{tabular}{|l|c|c|}
\hline \multicolumn{1}{|c|}{ Variables } & $\begin{array}{c}\text { Centre - Core } \\
\text { (102 firms) }\end{array}$ & $\begin{array}{c}\text { Periphery } \\
\text { (65 firms) }\end{array}$ \\
\hline Requirement to recruit next workers & $45 \%$ & $31 \%$ \\
\hline Wage higher than usual & $38 \%$ & $26 \%$ \\
\hline Requirement for university education & $47 \%$ & $25 \%$ \\
\hline Independence from other ICT firms - yes & $65 \%$ & $65 \%$ \\
\hline The difficulty of retaining your employees & $53 \%$ & $37 \%$ \\
\hline Awareness about 5 or more similar firms around & $56 \%$ & $23 \%$ \\
\hline $\begin{array}{l}\text { Do business in an environment with more similar } \\
\text { firms is positively perceived }\end{array}$ & $65 \%$ & $54 \%$ \\
\hline
\end{tabular}

Source: questionnaire survey, own processing, 2018. 
The histogram in Fig. 2 shows the cumulative responses for each concentration effect from both regions divided by the location of ICT firms in the centre and in the periphery. Respondents could choose more variants for answering this question. For this reason, the number of answers does not match the total number of addressed ICT firms.

The most positive assessment of the concentration for ICT firms is the natural pressure to continually innovate and improve existing processes in the company (with this answer agree 82 respondents what is $49 \%$ of all addressed firms, see also Fig. 3). There were 53 respondents from the centres $(52 \%)$ and 29 companies $(45 \%)$ on the periphery. Companies also appreciate better transfer of expertise, knowledge and information (25\% of firms from centres and $14 \%$ from peripherals). A qualified workforce is valued by firms located only in the centres of the regions (at 17\%). So, sectoral concentration has a positive impact on the number of skilled workers on the labour market and on easier sharing of information and knowledge. Increased competition among ICT firms in their agglomeration has a positive effect of the need to constantly innovate and improv processes.

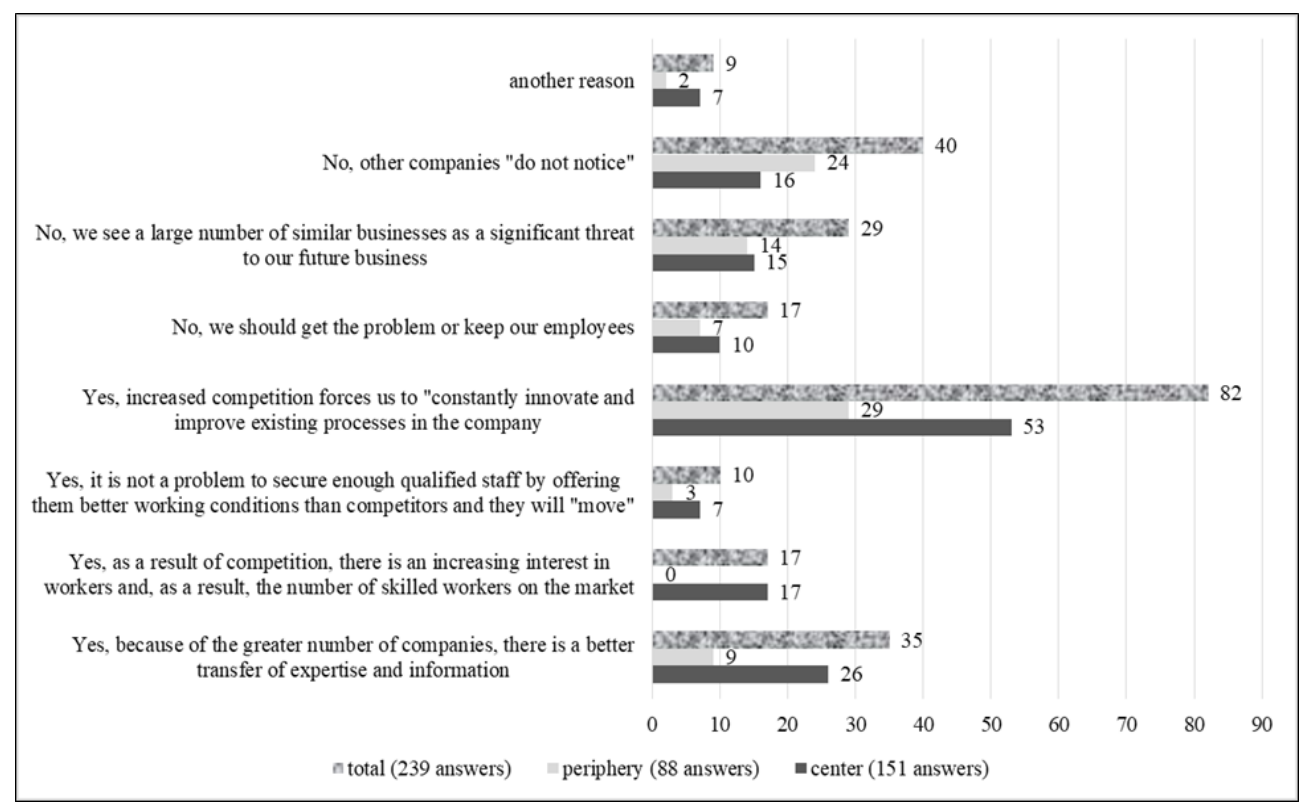

Fig. 2. Agglomeration effects of ICT firms in the core and periphery (number of responses). Sources: questionnaire survey, own processing, 2018.

Negative to increased competition is the feeling of a threat to another potential business (29 replies in total, 22\% of companies come from peripheral districts and only $16 \%$ from centres). However, many ICT firms have admitted that they do not notice the behaviour of other similar companies in their area (40 companies, i.e. 24\%), more companies in peripheral areas $(37 \%)$ voted for the answer. In the centres, it was only $16 \%$. This division of responses is typical in context of their localization in the core and in the periphery.

The results of agglomeration (concentration) effects correspond to the answers summarized in Table 2. The above information is complemented by the fact, get from the of questionnaire research, that independently of the location of ICT firms, these 
companies together work and cooperate from $90 \%$ but in $65 \%$ feel completely independent on other similar firms. The current favourable economic situation contributes, among other things, to the positive expectations of ICT companies regarding future developments while more than $88 \%$ of ICT companies anticipate further growth: increasing product production or provision of services, modernization of their production processes and technical infrastructure or expansion of current business partnership. Companies also consider increasing the number of their employees. For existing employees ICT firms generally, support further education and actively call for cooperation with other ICT companies.

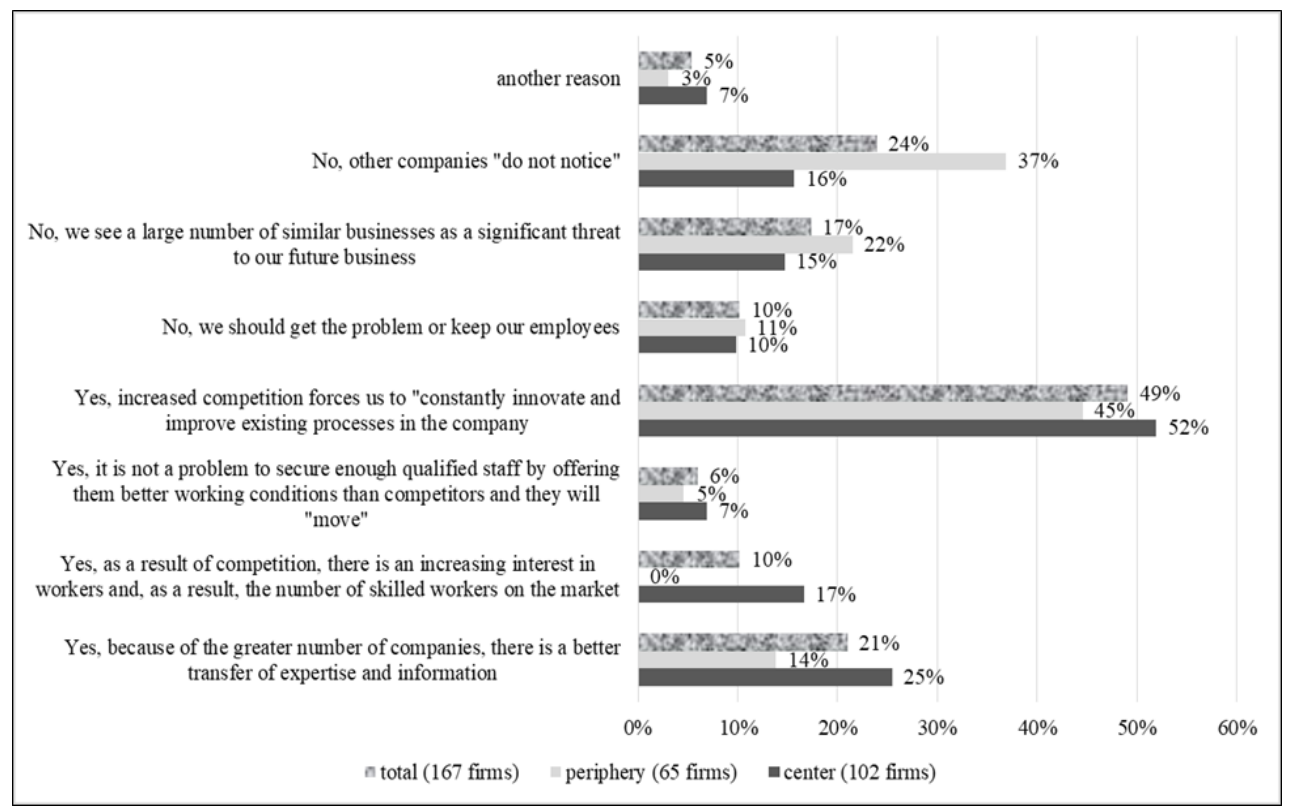

Fig. 3. Agglomeration effects of ICT firms in the core and periphery

(in \% of the number of companies).

Sources: questionnaire survey, own processing, 2018.

\section{CONCLUSIONS}

The aim of the paper was to examine the factors and contributions of the firm concentration and selected agglomeration effect, taking into consideration their location either in the core of the region or in its periphery. The case study was done on primary data gained from email questionnaire survey which was carried out in the Czech Republic in two regions on regional level NUTS3, The South Moravian Region and The Moravian-Silesian Region between firms doing their business in Information and Communication Technologies. Through the findings from the questionnaire survey and the background of the analysis of answers, we can find partial relevant links and elements between the examined issues and some specific theories of regional development, especially "coreperiphery" theory. 
From the concentration of the ICT sector, the following agglomeration effects are emerging for firms: the most positive element of the concentration of the ICT sector is that the addressed firms are pressured by competition, leading to the constant need to implement innovation (in a positive sense) in these companies and to improve their current processes and practices in their company. A total of 82 ICT firms (49\%) opted for this answer. 35 companies (21\%) perceive, as a further substantial benefit of sectoral concentration, easier exchange and transfer of expertise and knowledge and, in general, better access to information and data. The undesirable effect of sectoral concentration for the firms is the risk of failure in further (next) business (due to increased competition). This option was chosen by 29 companies, i.e. 17\%. Overall, the effects of the concentration of ICT companies are perceived by $61 \%$ as clearly positive what corresponded with another answer that $65 \%$ firms in the core and $54 \%$ in the periphery are aware generally of the positive effects of sectoral agglomeration. For "core" is more characteristic and are more pronounced these agglomeration advantages: (1) skilled and specialized workforce, (2) mutually reinforcing technology and innovation in the industry (necessity and response to competition), and (3) the interdependence of local businesses in the form of subcontracting and joint use of specialized infrastructure (in about 90\%). There is a need to add a significant cumulative effect that contributes to the region's specialization in certain economic activities, and thus positive expectations.

From the concept of sectoral industrial agglomerations, it is possible to emphasize the parallel between the actual findings and the thesis that the dissemination of information, knowledge, technological processes and practices and innovations enhances efficiency, success, growth dynamics and the competitiveness of the system itself.

\section{ACKNOWLEDGMENT}

This paper was supported by the project SGS/13/2015 "Influence of Selected Macroeconomic and Microeconomic Determinants on the Competitiveness of Regions and Firms in Countries of the Visegrad Group Plus".

\section{R E F E R E N C E S}

Baldwin, R., Forslid, R., Martin, P., Ottaviano, G. \& Robert-Nicoud, F. (2005). Economic Geography and Public Policy. University Presses of California, CA: Columbia and Princeton.

Basl, J. (2010). Př́ístupy a trendy $\mathrm{v}$ inovacích informačních a komunikačních technologií ve společnosti a ekonomice. [online] Available from: https://is.muni.cz/do/econ/soubory/oddeleni/centrum/papers/19Basl.pdf [Accessed 20th September 2017]

Campos, C. (2012). The Geographical Concentration of Industries. [online] Available from: Dostupné z: http://www.ons.gov.uk /ons/ dcp171766_272232.pdf. [Accessed 25th September 2017]

Czech Statistical Office. (2017). Database of the Business Register. [online] Available from: https://www.czso.cz/csu/res/business_register [Accessed 20th December 2017]

Driffield, N. \& Munday, M. (2001). Foreign manufacturing, regional agglomeration and technical efficiency in UK industries: A stochastic production frontier approach. Regional Studies 35(5), 391-399.

Friedman, T. L. (2006). The World is Flat - The globalized world in the Twenty-first century. 2nd edition. New York: Penguin Books.

Friedmann, J. (1966). Regional development policy: a case study of Venezuela. Cambridge: MIT Press.

Higgins, B. H., Higgins, B. \& Savoie, D. J. (1995). Regional development theories and their application. London: Transaction Publishers. 
Hirschman, A. O. (1967). Development Projects Observed. Washington, D. C.: The Brookings Institution.

Hong, J. \& Fu, S. (2011). Information and Communication Technologies and the Geographical Concentration of Manufacturing Industries. Urban studies 48(11), 2339-2354.

Kim, M. K., Harris, T. R. \& Vusovic, S. (2009). Efficiency analysis of the US biotechnology industry: Clustering enhances productivity. AgBioForum, 12(3-4), 422-436.

Lasuén, J. R. (1969). On growth poles, Urban Studies 6(2), 137-161.

Mitra, A. \& Sato, H. (2007). Agglomeration economies in Japan: Technical efficiency, growth and unemployment. Review of Urban and Regional Development Studies 19(3), 197-209.

Mitra, A. (1999). Agglomeration economies as manifested in technical efficiency at the firm level. Journal of Urban Economics 45(3), 490-500.

Myrdal, G. (1957). Economic Theory and Under-developed Regions. London: Gerald Duckwords.

North, D. (1955). Location Theory and Regional Economic Growth. Journal of Political Economy 63(3), 243-258.

Otsuka, A. \& Goto, M. (2015). Regional policy and the productive efficiency of Japanese industries. Regional Studies 49(4), 518-531.

Pařil, V., Kunc, J., Šasinka, P., Tonev, P. \& Viturka, M. (2015). Agglomeration effects of the Brno city (Czech Republic) as exemplified by the population labour mobility, Geographia Technica, 10(1), 66-76.

Perroux, F. (1950). Economic Space: Theory and Applications. The Quarternaly Journal of Economics 64(2), 89-104.

Regional Information Service. (2017). Maps. [online] Available from: http://www.risy.cz/cs/mapyke-stazeni [Accessed 10th September 2017]

Roche, E. M. (2016). Information and Communication Technology Still a Force for Good? Journal of global information technology management 19(2), 75-79.

Ruda, A. (2016). Exploring tourism possibilities using gis-based spatial association method, Geographia Technica, 11(2), 87-101.

Šimanová, J. \& Trešl, F. (2011). Vývoj průmyslové koncentrace a specializace v regionech NUTS3 České republiky v kontextu dynamizace regionální komparativní výhody. Ekonomie a management 1(1), 38-52.

Turečková, K. \& Nevima J. (2017). Cluster analysis in context of ICT sector in NUTS3 regions of Czech Republic. In: Proceedings of the 13th International Conference Liberec Economic Forum 2017. Liberec: Technical University of Liberec, 153-161.

Turečková, K. (2014). Dekompozice faktorů konkurenceschopnosti regionů v oblasti ICT sektoru. In: Sborník recenzovaných př́íspěvků z 2. ročníku mezinárodní vědecké konference Ekonomika a ř́zení podniku ve 21. století. Ostrava: VŠB-TU Ostrava, 187-193.

Turečková, K. (2015). Sectoral industrial agglomeration and network externalities: concept of ICT sector. In: Proceedings of 5th International Conference on Applied Social Science. USA: IERI, 50-55.

Turečková, K. (2017). Selected Microeconomic Effects of ICT firms in context of level of Sectoral Concentration: case study in selected regions of the Czech Republic, Trends Economics and Management 11(30), 61-72.

Tveteras, R. \& Battese, G. E. (2006). Agglomeration externalities, productivity and technical inefficiency. Journal of Regional Science 46(4), 605-625.

Wokoun, R. et al., (2008). Regionální rozvoj: východiska regionálního rozvoje, regionální politika, teorie, strategie a programování. Praha: Linde. 